\title{
Estimation of Serum and Salivary Sialic Acid Level in Patients with Oral Squamous Cell Carcinoma
}

\author{
Pratibha Poudel, ${ }^{1}$ Barsha Bajracharya, ${ }^{2}$ Shubrato Bhattacharyya, ${ }^{3}$ Dipshikha Bajracharya ${ }^{3}$ \\ ${ }^{1}$ Department of Oral Pathology, Kathmandu University School of Medical Sciences, Dhulikhel, Kavre, Nepal, \\ ${ }^{2}$ Department of Dentistry, Nepalese Army Institute of Health Sciences, Kathmandu, Nepal, ${ }^{3}$ Department of Oral \\ Pathology, Kantipur Dental College, Basundhara, Kathmandu.
}

\begin{abstract}
Background: Background: Sialic acid is a glycoprotein that is considered as an important constituent of cell membrane. Altered glycosylation is one of the important molecular changes that accompany malignant transformation. Several studies in past have shown that changes in serum and salivary sialic acid levels in cancer patients correlate well with tumor burden. Some of the findings suggested that sialic acid levels could be elevated in cancer patients before the occurrence of clinical symptoms. The purpose of this study is to estimate serum and salivary sialic acid level in oral squamous cell carcinoma patients and correlate their level with the histopathological grading of oral squamous cell carcinoma. Methods: Blood and saliva samples were collected from 50 patients with oral squamous cell carcinoma and 50 healthy subjects. Serum and salivary sialic acid levels in both free and protein bound forms were measured spectrophotometrically. This was correlated with histopathological grades of oral squamous cell carcinoma. The statistical analysis was done using SPSS software. Results: A statistically significant rise in serum and salivary sialic acid level was noted in OSCC subjects compared to the controls. Furthermore, significant difference in both serum and salivary sialic acid level was noted between well and poorly differentiated OSCC. Conclusions: Our report suggests that sialic acid is a valuable biomarker of oral squamous cell carcinoma. It may be used to assess the histological grading of oral cancer and predict the disease outcome and response to the therapy.
\end{abstract}

Keywords: sialic acid; squamous cell carcinoma; tumor biomarker.

\section{INTRODUCTION}

Cancer is considered as one of the most leading cause of death in the world. Among all cancer, oral cancer ranks $6^{\text {th }}$ position worldwide and $3^{\text {rd }}$ position in developing countries wherein oral squamous cell carcinoma (OSCC) accounts for $90 \%$ of the cases. ${ }^{1,2}$ Aberrant glycosylation of glycoconjugates is an important molecular change that accompanies malignant transformation. Sialic acids are terminal monosaccharides attached to cell surface glycoconjugates. They play an important role in cell to cell interactions and adhesion which is significant in malignant transformations. ${ }^{3,4}$ Cancer cells have been associated with increased activity of sialyltransferase leading to increased amount of sialic acid on the cell surface. This is then released into circulation due to secretion and shedding and thus increasing their level in body fluids such as serum and saliva. ${ }^{5}$ Our study was an attempt to estimate the level of serum and salivary free sialic acid (FSA) and protein bound sialic acid (PBSA) in OSCC patients and control group and correlate it with histopathological grading of OSCC.

\section{METHODS}

This is a cross sectional study conducted in Bhaktapur Cancer Hospital, Bhaktapur and
Kantipur Dental College, Kathmandu, Nepal from July 2015 to March 2016. Ethical approval was obtained from ethics and research committee of Kantipur Dental College and permission was obtained from Bhaktapur Cancer Hospital prior starting any study related procedure. Similarly collection of sample was done only after obtaining informed consent from the patients. The study comprised of two groups: first group consisted of 50 OSCC patients that were confirmed histologically whereas second group consisted of 50 age and sex matched healthy controls. Patients with systemic disease such as subacute granulomatous thyroiditis, Crohn's disease, diabetes, atherosclerosis, glomerulonephritis, chronic liver failure, and pneumonia were excluded. ${ }^{6}$

Blood sample $(5 \mathrm{ml})$ was collected using disposable syringes by a trained health practitioner. The collection of blood from the sample population was done in vacutainers without any anticoagulant coating. After one hour, vacutainers were centrifuged at $3000 \mathrm{rpm}$ for 15 minutes (mins) and serum was separated from the clotted blood.

Correspondence: Dr. Pratibha Poudel, Department of Oral Pathology, Kathmandu University School of Medical Sciences, Dhulikhel, Kavre, Nepal. Email: poudelpratibha@gmail.com. Phone: +977-9851231988. Article received: 2019-04-21. Article accepted: 2019-07-17. 
The collection of saliva samples were done between 9.00-11.00 am to avoid any possible diurnal variation. The subjects were first asked to rinse the mouth with distilled water thoroughly. The unstimulated whole saliva sample $(2 \mathrm{ml})$ was then collected after 5 mins by spitting method into a small sterile plastic container. They were instructed not to spit forcibly so as to avoid blood contamination (if any) from inflamed gingival tissue or ulcerated lesion. After the serum and saliva samples were collected they were stored in $-20^{\circ} \mathrm{C}$ to $-80^{\circ} \mathrm{C}$ till assayed. ${ }^{8,9}$ The acidic ninhydrin reagent was prepared according to Gaitonde (1967). ${ }^{10}$ Estimation of PBSA in serum and saliva and FSA in saliva were done using the method of Yao et al. ${ }^{11,4}$ FSA level in serum was analysed using the method of Skoza and Mohos. ${ }^{4,12}$ The values of biochemical parameters thus obtained were tabulated and analyzed statistically using SPSS software version 23.0.

The comparison of mean values of sialic acid between cancer patients and control group was done with the help of Mann Whitney U test. Association of free and protein bound sialic acid with various histological grading of OSCC was tested using ANOVA. The comparison of mean sialic acid levels between pre-treatment cases and patients receiving the treatment was done using independent sample T test. Further correlation was done between duration of treatment and sialic acid levels by using Pearson's correlation coefficient.

\section{RESULTS}

The present study comprised of 100 subjects out of which $72 \%$ were males and $28 \%$ were females. The demographic data and distribution of subjects in study is given in Table 1. In the present study, we

\begin{tabular}{|c|c|c|}
\hline$\overline{\text { Variable }}$ & Count & Percentage \\
\hline \multicolumn{3}{|l|}{ Groups: } \\
\hline Group I = Control & 50 & $50 \%$ \\
\hline Group II $=$ OSCC patients & 50 & $50 \%$ \\
\hline \multicolumn{3}{|l|}{ Gender: } \\
\hline Group I & $\mathrm{M}=36, \mathrm{~F}=14$ & $\mathrm{M}=72 \%, \mathrm{~F}=28 \%$ \\
\hline Group II & $M=36, F=14$ & $\mathrm{M}=72 \%, \mathrm{~F}=28 \%$ \\
\hline \multicolumn{3}{|l|}{ TNM staging: } \\
\hline Stage I & 09 & $18.0 \%$ \\
\hline Stage II & 16 & $32.0 \%$ \\
\hline Stage III & 09 & $18.0 \%$ \\
\hline Stage IV & 16 & $32.0 \%$ \\
\hline \multicolumn{3}{|l|}{ Histological grading } \\
\hline Well differentiated & 35 & $70.0 \%$ \\
\hline Moderately differentiated & 12 & $24.0 \%$ \\
\hline Poorly differentiated & 03 & $06.0 \%$ \\
\hline \multicolumn{3}{|l|}{ Treatment modalities: } \\
\hline Pre treatment & 20 & $40.0 \%$ \\
\hline Radiotherapy & 14 & $28.0 \%$ \\
\hline Surgery & 08 & $16.0 \%$ \\
\hline Surgery + Radiotherapy & 08 & $16.0 \%$ \\
\hline
\end{tabular}

observed significant increase in serum and salivary sialic acid levels (both protein bound and free) in OSCC patients compared to the control group $(p<0.001$; Table 2$)$. We compared mean sialic acid levels with three grades of OSCC with the help of

\begin{tabular}{|c|c|c|c|c|c|c|}
\hline $\begin{array}{l}\text { Table } \\
\text { the } O\end{array}$ & $\begin{array}{r}\text { Cor } \\
\text { C pa }\end{array}$ & $\begin{array}{l}\text { ariso } \\
\text { nts a }\end{array}$ & is & a & $\begin{array}{l}\text { levels } \\
\text { ls. }\end{array}$ & ween \\
\hline $\begin{array}{l}\text { Param- } \\
\text { eters }\end{array}$ & Group & $\begin{array}{l}\text { Mean } \\
(\mathrm{mg} / \mathrm{dl})\end{array}$ & $\overline{S D}$ & $\begin{array}{l}\text { Mean } \\
\text { rank }\end{array}$ & $\begin{array}{l}\text { Sum of } \\
\text { ranks }\end{array}$ & P value \\
\hline $\begin{array}{l}\text { Sali- } \\
\text { vary }\end{array}$ & $\begin{array}{l}\text { OSCC } \\
\text { patients }\end{array}$ & 0.494 & 0.419 & 74.69 & 3734.50 & $<0.001^{*}$ \\
\hline PBSA & $\begin{array}{l}\text { Healthy } \\
\text { controls }\end{array}$ & 0.092 & 0.038 & 26.31 & 1315.50 & \\
\hline $\begin{array}{l}\text { Sali- } \\
\text { vary }\end{array}$ & $\begin{array}{l}\text { OSCC } \\
\text { patients }\end{array}$ & 0.936 & 0.391 & 74.27 & 3713.50 & $<0.001^{*}$ \\
\hline FSA & $\begin{array}{l}\text { Healthy } \\
\text { controls }\end{array}$ & 0.401 & 0.138 & 26.73 & 1336.50 & \\
\hline $\begin{array}{l}\text { Serum } \\
\text { PBSA }\end{array}$ & $\begin{array}{l}\text { OSCC } \\
\text { patients }\end{array}$ & 61.347 & 12.84 & 75.50 & 3775.0 & $<0.001 *$ \\
\hline & $\begin{array}{l}\text { Healthy } \\
\text { controls }\end{array}$ & 19.21 & 5.07 & 25.50 & 1275.0 & \\
\hline $\begin{array}{l}\text { Serum } \\
\text { FSA }\end{array}$ & $\begin{array}{l}\text { OSCC } \\
\text { patients }\end{array}$ & 0.810 & 0.193 & 75.50 & 3775.0 & $<0.001 *$ \\
\hline & $\begin{array}{l}\text { Healthy } \\
\text { controls }\end{array}$ & 0.276 & 0.070 & 25.50 & 1275.0 & \\
\hline
\end{tabular}

ANOVA test and applied post hoc comparisons through least significant difference (LSD) test. The results showed that mean salivary protein bound sialic acid level was significantly lower in well differentiated OSCC compared to moderately differentiated and poorly differentiated OSCC with 'p' values 0.001 and 0.004 respectively (Table 3 ).

\begin{tabular}{|c|c|c|c|c|c|}
\hline \multirow[t]{2}{*}{$\begin{array}{l}\text { Grading } \\
(\text { mean } \pm \text { sd })\end{array}$} & \multirow{2}{*}{$\begin{array}{l}\text { Comparison } \\
\text { Group } \\
(\text { mean } \pm \text { sd })\end{array}$} & \multirow[t]{2}{*}{$\begin{array}{l}\text { Mean } \\
\text { Diff. }\end{array}$} & \multicolumn{2}{|c|}{$\begin{array}{l}95 \% \text { CI of mean } \\
\text { Diff. }\end{array}$} & \multirow[t]{2}{*}{$\begin{array}{l}\mathbf{P} \\
\text { value }\end{array}$} \\
\hline & & & Lower & Upper & \\
\hline \multirow{2}{*}{$\begin{array}{l}\text { Well differ- } \\
\text { entiated } \\
(0.317 \pm \\
\mathbf{0 . 2 3 1 )}\end{array}$} & $\begin{array}{l}\text { Moderately } \\
\text { differentiated } \\
(0.906 \pm \\
0.468)\end{array}$ & -0.589 & -0.808 & -0.370 & 0.001* \\
\hline & $\begin{array}{l}\text { Poorly differ- } \\
\text { entiated } \\
(0.916 \pm \\
0.604)\end{array}$ & -0.599 & -0.992 & -0.206 & $0.004 *$ \\
\hline $\begin{array}{l}\text { Moderately } \\
\text { differentiat- } \\
\text { ed } \\
(\mathbf{0 . 9 0 6} \pm \\
\mathbf{0 . 4 6 8 )}\end{array}$ & $\begin{array}{l}\text { Poorly differ- } \\
\text { entiated } \\
(0.916 \pm \\
0.604)\end{array}$ & -0.010 & -0.432 & 0.412 & 0.962 \\
\hline
\end{tabular}

The mean difference of salivary free sialic acid was significant only between well differentiated and poorly differentiated $(\mathrm{p}=0.001)$ and between moderately differentiated and poorly differentiated $(p=0.015$; Table 4$)$. In case of serum protein bound

\begin{tabular}{|c|c|c|c|c|c|}
\hline $\begin{array}{l}\text { Table } 4 \\
\text { with his }\end{array}$ & $\begin{array}{l}\text { ssociation } \\
\text { ogical gra }\end{array}$ & $\begin{array}{l}\text { Saliv } \\
\text { g of }\end{array}$ & C. & & \\
\hline $\begin{array}{l}\text { Grading } \\
(\text { mean } \pm d)\end{array}$ & $\begin{array}{l}\text { Comparison } \\
\text { Group }\end{array}$ & $\begin{array}{l}\text { Mean } \\
\text { Diff. }\end{array}$ & $95 \% \mathrm{C}$ & $\begin{array}{l}\text { f mean } \\
\text { f. }\end{array}$ & $\mathrm{P}$ value \\
\hline & $(\mathrm{mean} \pm \mathrm{sd})$ & & Lower & Upper & \\
\hline $\begin{array}{l}\text { Well } \\
\text { differenti- } \\
\text { ated } \\
(\mathbf{0 . 8 5 4} \pm\end{array}$ & $\begin{array}{l}\text { Moderately } \\
\text { differentiated } \\
(1.013 \pm \\
0.359)\end{array}$ & -0.159 & -0.398 & 0.080 & 0.187 \\
\hline 0.292$)$ & $\begin{array}{l}\text { Poorly differ- } \\
\text { entiated } \\
(1.590 \pm 0.896)\end{array}$ & -0.735 & -1.165 & -0.305 & 0.001 * \\
\hline $\begin{array}{l}\text { Moder- } \\
\text { ately } \\
\text { differenti- } \\
\text { ated } \\
(\mathbf{1 . 0 1 3} \pm \\
\text { (.359) }\end{array}$ & $\begin{array}{l}\text { Poorly differ- } \\
\text { entiated } \\
(1.590 \pm 0.896)\end{array}$ & -0.576 & -1.038 & -0.115 & $0.015^{*}$ \\
\hline
\end{tabular}

sialic acid, the mean difference was significant between well and poorly differentiated OSCC 
$(\mathrm{p}<0.001)$ and moderate and poorly differentiated OSCC $(p<0.001$; Table 5) whereas for serum free

\begin{tabular}{|c|c|c|c|c|c|}
\hline \multicolumn{6}{|c|}{$\begin{array}{l}\text { Table 5. Association of serum protein bound sialic } \\
\text { acid level with histological grading of OSCC. }\end{array}$} \\
\hline \multirow[t]{2}{*}{$\begin{array}{l}\text { Grading } \\
(\text { mean } \pm \text { sd })\end{array}$} & \multirow{2}{*}{$\begin{array}{l}\text { Comparison } \\
\text { Group } \\
(\text { mean } \pm \text { sd) }\end{array}$} & \multirow[t]{2}{*}{$\begin{array}{l}\text { Mean } \\
\text { Diff. }\end{array}$} & \multicolumn{2}{|c|}{$\begin{array}{l}\text { 95\% CI of mean } \\
\text { Diff. }\end{array}$} & \multirow[t]{2}{*}{ P value } \\
\hline & & & Lower & Upper & \\
\hline \multirow{4}{*}{$\begin{array}{l}\text { Well dif- } \\
\text { ferentiated } \\
(\mathbf{5 8 . 8 2} \pm \\
\mathbf{1 1 . 0 2 2 )}\end{array}$} & $\begin{array}{l}\text { Moderately } \\
\text { differentiated }\end{array}$ & -3.009 & -10.35 & 4.33 & 0.414 \\
\hline & $\begin{array}{l}(61.83 \quad \pm \\
11.46)\end{array}$ & & & & \\
\hline & Poorly dif- & -30.005 & -43.21 & -16.79 & $<0.001 *$ \\
\hline & $\begin{array}{l}\text { ferentiated } \\
(88.83 \\
3.172)\end{array}$ & & & & \\
\hline $\begin{array}{l}\text { Moderate- } \\
\text { ly differ- } \\
\text { entiated } \\
(\mathbf{6 1 . 8 3} \\
\mathbf{1 1 . 4 6 0 )}\end{array}$ & $\begin{array}{l}\text { Poorly dif- } \\
\text { ferentiated } \\
(88.83 \\
3.172)\end{array} \quad \pm$ & -26.995 & -41.16 & -12.82 & $<0.001^{*}$ \\
\hline
\end{tabular}

sialic acid the mean level was found to increase significantly in moderately differentiated OSCC $(\mathrm{p}=0.003)$ and poorly differentiated OSCC $(\mathrm{p}=0.041)$ compared to well differentiated. However, the further rise in mean levels from moderately differentiated to poorly differentiated was not significant ( $\mathrm{p}=0.744$; Table 6 ).

\begin{tabular}{|c|c|c|c|c|c|}
\hline \multicolumn{6}{|c|}{$\begin{array}{l}\text { Table 6. Association of serum free sialic acid level } \\
\text { with histological grading of OSCC. }\end{array}$} \\
\hline \multirow[t]{2}{*}{$\begin{array}{l}\text { Grading } \\
(\text { mean } \pm \text { sd) }\end{array}$} & \multirow{2}{*}{$\begin{array}{l}\text { Comparison } \\
\text { Group } \\
(\text { mean } \pm \text { sd) }\end{array}$} & \multirow[t]{2}{*}{$\begin{array}{l}\text { Mean } \\
\text { Diff. }\end{array}$} & \multicolumn{2}{|c|}{$\begin{array}{l}95 \% \text { CI of mean } \\
\text { Diff. }\end{array}$} & \multirow[t]{2}{*}{$\begin{array}{l}\mathbf{P} \\
\text { value }\end{array}$} \\
\hline & & & Lower & Upper & \\
\hline \multirow{2}{*}{$\begin{array}{l}\text { Well } \\
\text { differenti- } \\
\text { ated } \\
(\mathbf{0 . 7 5 2} \pm \\
\mathbf{0 . 1 5 7 )}\end{array}$} & $\begin{array}{l}\text { Moderately } \\
\text { differentiated } \\
(0.937 \pm 0.174)\end{array}$ & -0.184 & -0.302 & -0.066 & $0.003^{*}$ \\
\hline & $\begin{array}{l}\text { Poorly differ- } \\
\text { entiated } \\
(0.974 \pm 0.368)\end{array}$ & -0.221 & -0.434 & -0.009 & $0.041^{*}$ \\
\hline $\begin{array}{l}\text { Moderate- } \\
\text { ly differ- } \\
\text { entiated } \\
(\mathbf{0 . 9 3 7} \pm \\
\mathbf{0 . 1 7 4 )}\end{array}$ & $\begin{array}{l}\text { Poorly differ- } \\
\text { entiated } \\
(0.974 \pm 0.368)\end{array}$ & -0.037 & -0.265 & 0.1908 & 0.744 \\
\hline
\end{tabular}

We also tried to compare mean sialic acid levels between pre-treatment cases and patients receiving the treatment using independent sample $\mathrm{T}$ test and found that mean sialic acid levels (both serum and salivary) were higher in pre-treatment patients compared to patients undergoing treatment. However, the mean difference between these two groups did not vary significantly $(\mathrm{p}>0.05)$. On correlating the duration of treatment (in months) and sialic acid levels by using Pearson's correlation coefficient, we found negative correlation between the two variables. Significant $(p<0.05)$ negative correlation was seen in free salivary sialic acid $(\mathrm{r}=$ $0.393)$ and protein bound serum sialic acid ( $\mathrm{r}=$ 0.286 ) however in other two sialic acid levels, the negative correlation was not strong and thus failed to reach statistical significance (Table 7).

\begin{tabular}{|l|ll|}
\hline \multicolumn{3}{|l|}{ Table 7. Correlation of duration of treatment (in } \\
months) with sialic acid levels in patients of & OSCC. \\
\hline Sialic acid & $\begin{array}{l}\text { Correlation } \\
\text { coefficient (r) }\end{array}$ & P value \\
& -0.227 & 0.112 \\
Protein bound salivary sialic acid & -0.393 & $\mathbf{0 . 0 0 5}$ \\
Free salivary sialic acid & -0.286 & $\mathbf{0 . 0 4 4}$ \\
Protein bound serum sialic acid & -0.120 & 0.405 \\
Free serum sialic acid & & \\
\hline \hline
\end{tabular}

\section{DISCUSSION}

Oral squamous cell carcinoma is the most common malignancy of the oral cavity. ${ }^{13}$ It has high mortality and morbidity rate despite the advances in the diagnostic techniques and treatment modalities. ${ }^{14}$ Early diagnosis of oral cancer can significantly decrease the mortality rate associated with this disease. ${ }^{15}$ Several studies have shown progressive rise in sialic acid levels from precancerous condition to oral cancer. ${ }^{4}$ Some of the findings suggested that sialic acid levels could be elevated in cancer patients before the occurrence of clinical symptoms. In addition several reports have described decrease in sialic acid levels after successful treatment of cancer and elevation of its level after recurrence of the disease. This suggests that sialic acid level could be used as diagnostic marker for early detection of oral cancer and monitoring the treatment response. ${ }^{6}$ Estimation of sialic acid in serum may act as an adjunct to conventional biopsy and salivary sialic acid estimation may provide a noninvasive and cost-effective method for screening the oral cancer patients. $^{16,17}$

In the present study, we observed that the mean rank of serum and salivary sialic acid levels (both protein bound and free) was three times higher among OSCC patients compared to the healthy controls. This signifies the fact that both serum and salivary sialic acid level can be used as an indicator of malignancy. The elevated levels of free and protein bound sialic acid in both serum and saliva of OSCC patients compared to the control follows the same trend observed by several authors. ${ }^{4,18-20}$ This can be due to altered glycosylation occuring during oncogenesis. Glycosylation of protein involves a series of reaction catalyzed by various membrane bound glycosyltransferase. In malignancy, these glycosyltransferases are mutated due to which abnormal glycoconjugates that have an increased size of oligosaccharides are produced. This results in more branching sites for the incorporation of sialic acid. ${ }^{4}$

We also tried to find the association of all four types of sialic acid levels measurements with the histological grading of OSCC. The value of salivary free sialic acid was statistically significant between well and moderately differentiated OSCC and well and poorly differentiated OSCC. However between moderately and poorly differentiated OSCC the values were not statistically significant. This may be because of insufficient sample size in poorly differentiated OSCC. Our findings are in agreement to the finding of Dhakar et al. who reported significantly increased salivary sialic acid level with increasing level of histopathological grading. ${ }^{18}$ In case of salivary protein bound sialic acid statistically significant difference was seen between well differentiated and poorly 
differentiated cases and between moderately differentiated and poorly differentiated cases. There was no significant difference in mean levels between well and moderately differentiated OSCC, which may be due to the subjective variation in grading of OSCC. As the histological grading changes from well differentiated to moderate and poor, the mean serum protein bound sialic acid level was also found to be increased however, for serum free sialic acid level significant rise was seen between moderately differentiated and poorly differentiated OSCC compared to well differentiated. The further rise in mean levels from moderately differentiated to poorly differentiated was not significant which could be due to fewer sample size in poorly differentiated group. Rajpura et al. $^{21}$ and Joshi et al. ${ }^{22}$ found statistically significant values of serum total sialic acid between well differentiated and poorly differentiated OSCC. The higher levels of sialic acid in poorly differentiated OSCC may be due to the less differentiation of tumor cells and increased tumor burden. Sialic acid increases at the tumor cell surface and is released through increased turnover, secretion and shedding of these malignant cells. ${ }^{21}$ This suggests that sialic acid could be used as effective tool to assess the tumor burden. Thus, in our study we found significantly higher mean values of serum and salivary sialic acid (both protein bound and free) in poorly differentiated OSCC compared to well differentiated OSCC which is in accordance to the findings of Dhakar et al. ${ }^{18}$

The current study also explored the sialic acid levels among pretreatment cases and post treatment cases. We found that mean sialic acid levels of both serum and saliva were higher in pretreatment patients compared to patient undergoing treatment although it was not statistically significant. Our study also showed that as the duration of treatment increases, the level of sialic acid decreases among the patients suffering from OSCC. Our results are in accordance to the result obtained by several investigators. $^{3,23}$ Taqi et al. in their study have mentioned that fall in serum sialic acid level occurs in postoperative patients who respond well to the treatment and rise in sialic acid level may occur in non responders. ${ }^{23}$ Trivedi et al. also reported significantly lower level of free and protein bound sialic acid in saliva fifteen days after the radiotherapy compared to the value observed before radiotherapy. ${ }^{3}$ This signifies that sialic acid level is directly related to the tumor burden and it could be used as adjunctive diagnostic marker in oral cancer. $^{22}$

Thus in the present study we observed a consistent elevation in serum and salivary sialic acid level (both protein bound and free) from normal to oral cancer and also from well differentiated OSCC to poorly differentiated OSCC. We also observed significant negative correlation between sialic acid levels and duration of treatment. However our preliminary observations need to be validated by further studies with large number of sample.

\section{CONCLUSIONS}

Based on our observations and previous reports, we suggest that sialic acid is a valuable biomarker for OSCC. It may be used to assess the histological grading of oral cancer and more importantly to predict the disease outcome and response to the therapy. However larger samples are necessary to confirm these observations.

\section{ACKNOWLEDGEMENTS}

We would like to acknowledge Mr. Anil Singh Basnyat, Dr. Samarika Dahal, Mr. Narayan Gautam and Dr. Bishow Raj Timalsina for their help during the study.

\section{REFERENCES}

1. Johnson N. Tobacco use and oral cancer: a global perspective. Journal of dental education. 2001;65(4):328-39. PMID: 11336118

2. Massano J, Regateiro FS, Januário G, Ferreira A. Oral squamous cell carcinoma: review of prognostic and predictive factors. Oral Surg Oral Med Oral Pathol Oral Radiol Endod. 2006;102(1):67-76. doi: 10.1016/ j.tripleo.2005.07.038. PMID: 16831675

3. Trivedi DJ, Trivedi MSCD, Hallikeri K, Udupa R. Salivary sialic acid as marker of oral cancer. Int J Integr Sci Innov Technol. 2012;1(1):4850. [Full text: http://ijiit.webs.com/ documents/120101-09.pdf]

4. Dahal S, Boaz K, Srikant N, Reshma K, Agrawal N. Micronuclei and sialic acid as markers of genotoxic damage in tobacco-related

oral lesions. J Pathol Nepal. 2013;3:379-84. doi: http://dx.doi.org/10.3126/jpn.v3i5.7862.

5. Kurtul N, Cil M, Bakan E. The effects of alcohol and smoking on serum, saliva, and urine sialic acid levels. Saudi Med J. 2004;25 (12):1839-44. PMID: 15711651

6. Sillanaukee P, Ponnio M, P.I J. Occurrence of sialic acids in healthy humans and different disorders. Eur J Cinical Investigtion. 1999;29:413-25. https://doi.org/10.1046/j.1365 -2362.1999.00485.x. PMID: 10354198

7. Sawhney H, Kumar CA. Correlation of serum biomarkers ( TSA \& LSA ) and epithelial dysplasia in early diagnosis of oral precancer and oral cancer. Cancer Biomark. 2012;10:439. doi: $10.3233 / \mathrm{CBM}-2012-0226$

8. Gokul S. Salivary Diagnostics in Oral Cancer. Intech Open Access Publisher; 2012. 
9. Sanjay P, Hallikeri K, Shivashankara A. Evaluation of salivary sialic acid, total protein, and total sugar in oral cancer: a preliminary report. Indian J Dent Res. 2008;19(4):288-91. PMID: 19075429

10. Gaitonde MK. A spectrophotometric method for the direct determination of cysteine in the presence of other naturally occurring amino acids. Biochem J. 1967;104(2):627-33. PMID: 6048802

11. Yao K, Ubuka T. Determination of sialic acids by acidic ninhydrin reaction. Acta Med Okayama. 1987;41(6):237-41. doi: 10.18926/ AMO/31741. PMID: 3439478

12. Chrostek L, Cylwik B, Krawiec A, Korcz W, Szmitkowski M. Relationship between serum sialic acid and sialylated glycoproteins in alcoholics. Alcohol Alcohol. 2007;42(6):588-2. doi: 10.1093/alcalc/agm048. PMID: 17573378

13. Feller L, Lemmer J. Oral Squamous Cell Carcinoma: Epidemiology , Clinical Presentation and Treatment. J Cancer Ther. 2012;3:263-8. doi: 10.4236/jct.2012.34037

14. Messadi D V. Diagnostic aids for detection of oral precancerous conditions. Int $\mathrm{J}$ Oral Sci. 2013;5(2):59-65. doi: 10.1038/ijos.2013.24. PMID: 23743617

15. Bagan J, Sarrion G, Jimenez Y. Oral cancer: Clinical features. Oral Oncol. 2010;46(6):414 7. doi: 10.1016/j.oraloncology.2010.03.009. PMID: 20400366

16. Chaudhari V, Pradeep G, Prakash N, Mahajan A. Estimation of salivary sialic acid in oral premalignancy and oral squamous cell carcinoma. Contemp Clin Dent. 2016;7(4):451. doi: 10.4103/0976-237X.194108. PMID: 27994410

17. Dadhich M, Prabhu V, Vr P, Souza DJ, Harish $\mathrm{S}$, Jose M. Serum and salivary sialic acid as a biomarker in oral potentially malignant disorders and oral cancer. Indian $\mathrm{J}$ Cancer. 2014;51(3):214-8. doi: 10.4103/0019509X.146720. PMID: 25494107

18. Dhakar N, Astekar M, Jain M, Saawarn S, Saawarn N. Total sialic acid, total protein and total sugar levels in serum and saliva of oral squamous cell carcinoma patients: A case control study. Dent Res J (Isfahan). 2013;10 (3):343-7. doi: 10.4103/1735-3327.115155. PMID: 24019802

19. Rao VR, Krishnamoorthy L, Kumaraswamy S V, Ramaswamy G. Circulating levels in serum of total sialic acid, lipid-associated sialic acid, and fucose in precancerous lesion and cancer of the oral cavity. Cancer Detect Prev. 1997;22 (3):237-40. PMID: 9618045

20. Rawal RM, Patel PS, Patel BP, Raval GN, Patel MM, Bhatavdekar JM, et al. Evaluation of glycoprotein constituents in head and neck cancer patients undergoing radiotherapy. Head Neck. 1999;21(3):192-7. PMID: 10208660

21. Rajpura KB, Patel PS, Chawda JG, Shah RM. Clinical significance of total and lipid bound sialic acid levels in oral pre-cancerous conditions and oral cancer. J Oral Pathol Med. 2005;34:263-7. doi: 10.1111/j.16000714.2004.00210.x. PMID: 15817068

22. Joshi M, Patil RR. Estimation and comparative study of serum total sialic acid levels as tumor markers in oral cancer and precancer. J Cancer Res Ther. 2010;6(3):263-6. doi: 10.4103/09731482.73339

23. Taqi SA. Clinical evaluation of total and lipid bound sialic acid levels in oral precancer and oral cancer. Indian J Med Paediatr Oncol. 2012;33(1):36-42. doi: 10.4103/09715851.96967. PMID: 22754207

Citation: Poudel P, Bajracharya B, Bhattacharyya S, Bajracharya D. Estimation of Serum and Salivary Sialic Acid Level in Patients with Oral Squamous Cell Carcinoma. JCMS Nepal. 2019; 15(3):186-90. 